\title{
Fotografando no Teatro Oficina ${ }^{1}$
}

\author{
Photographing at Teatro Oficina \\ João Caldas
}

João Caldas

Paulista, paulistano, há 40 anos vem registrando espetáculos de artes cênicas na cidade, trabalhou no Centro Cultural São Paulo em 1982 e na Folha de São Paulo de 1985 a 1987, desde então segue como fotógrafo free lancer e apaixonado por teatro

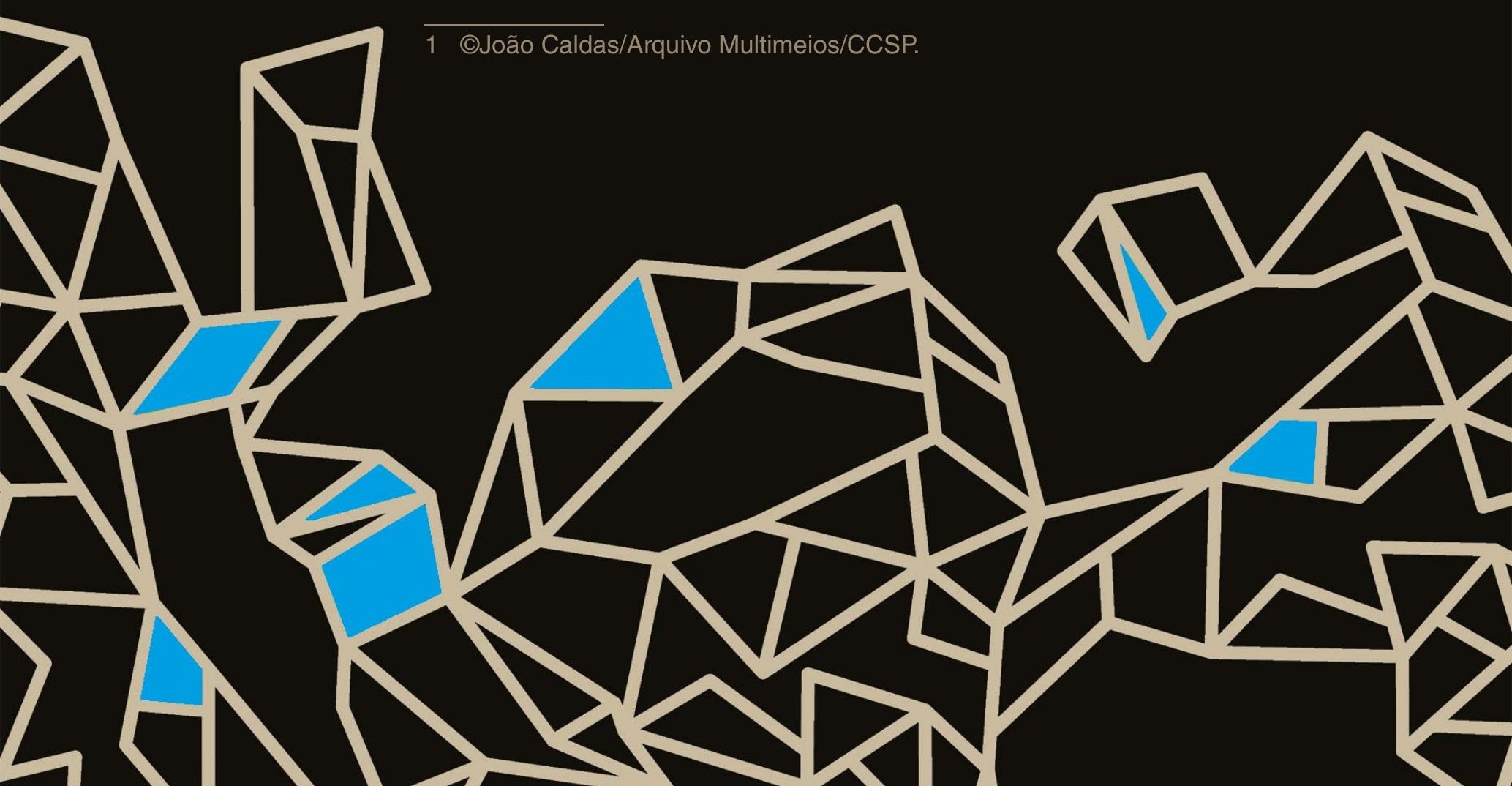



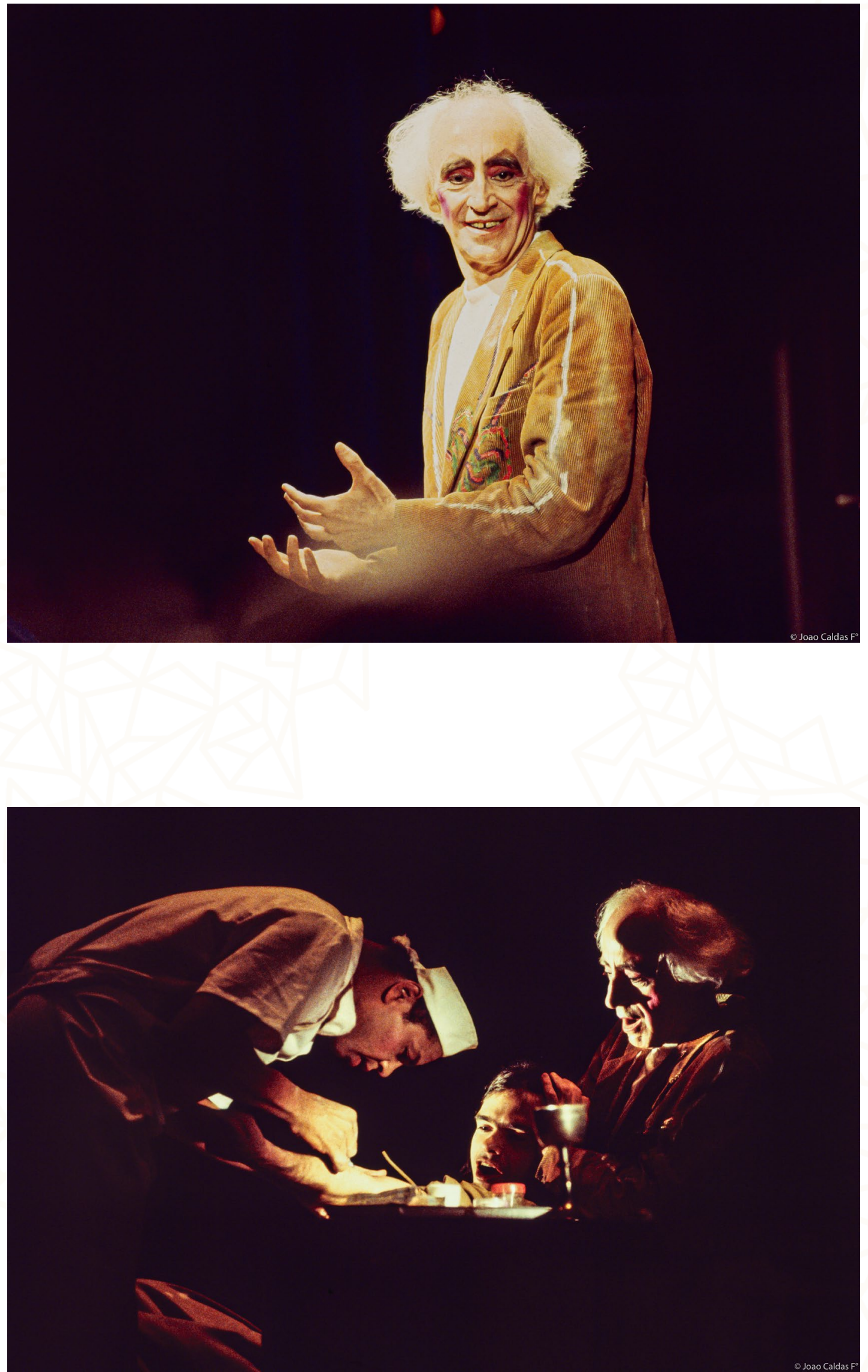


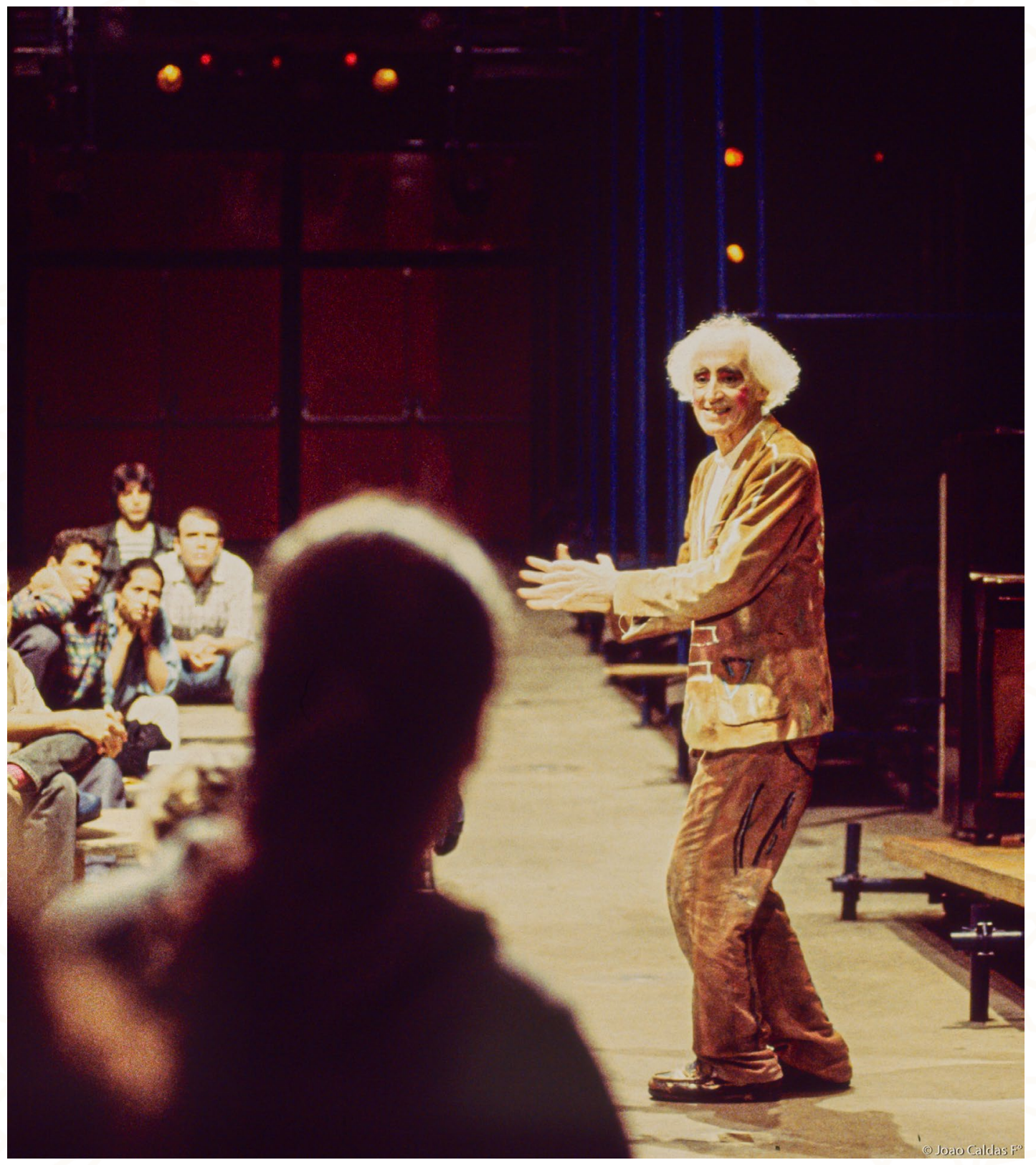




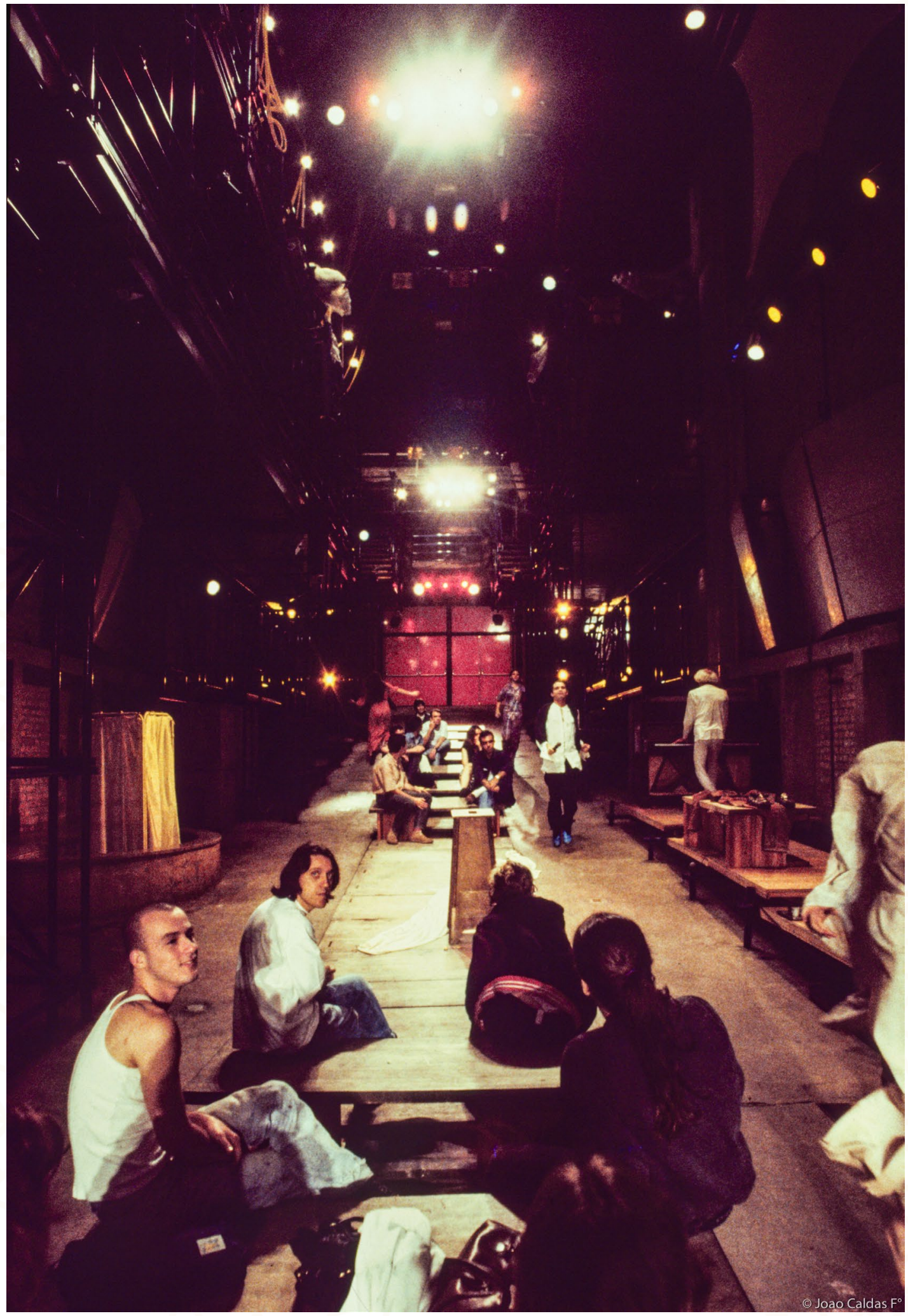




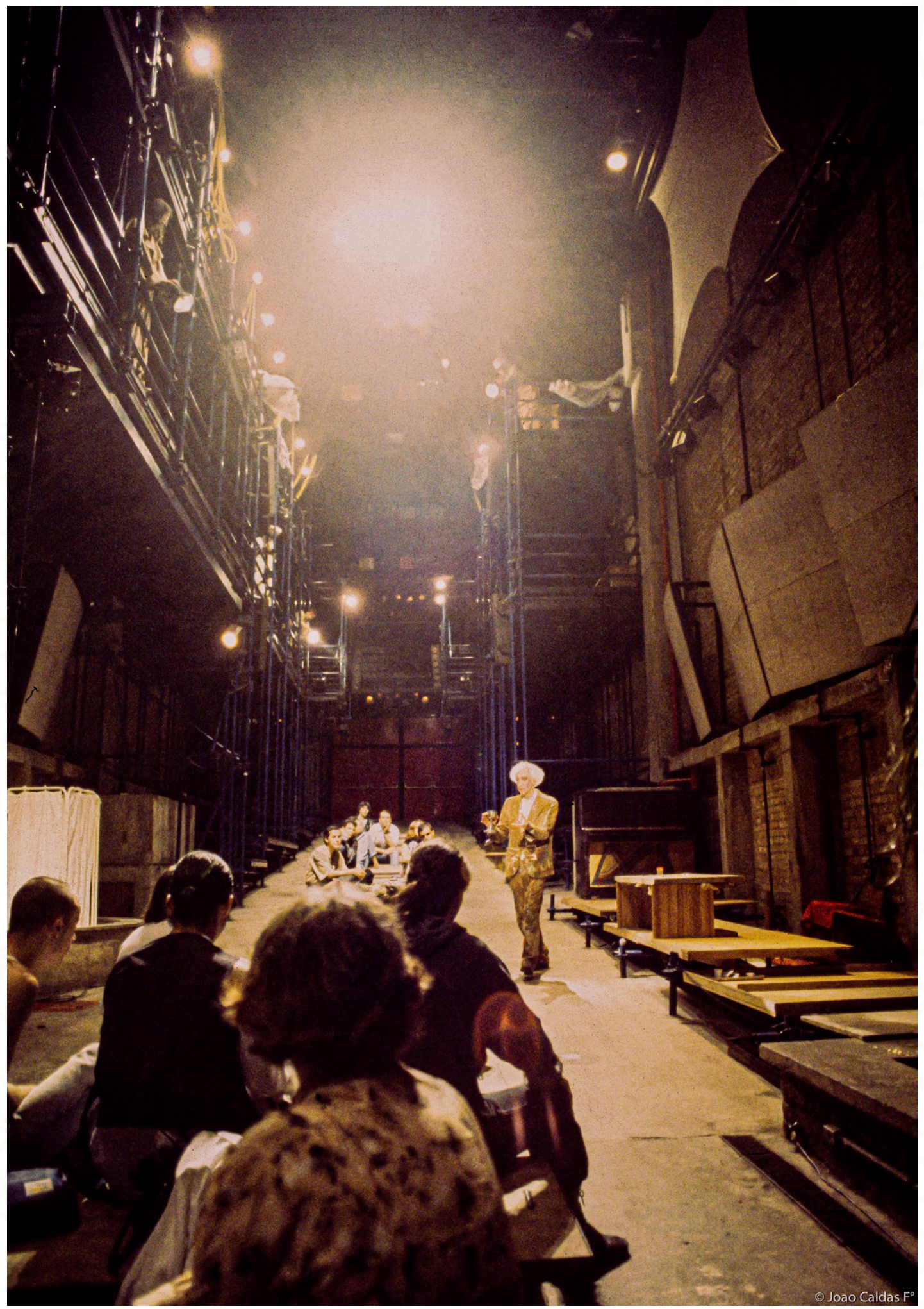




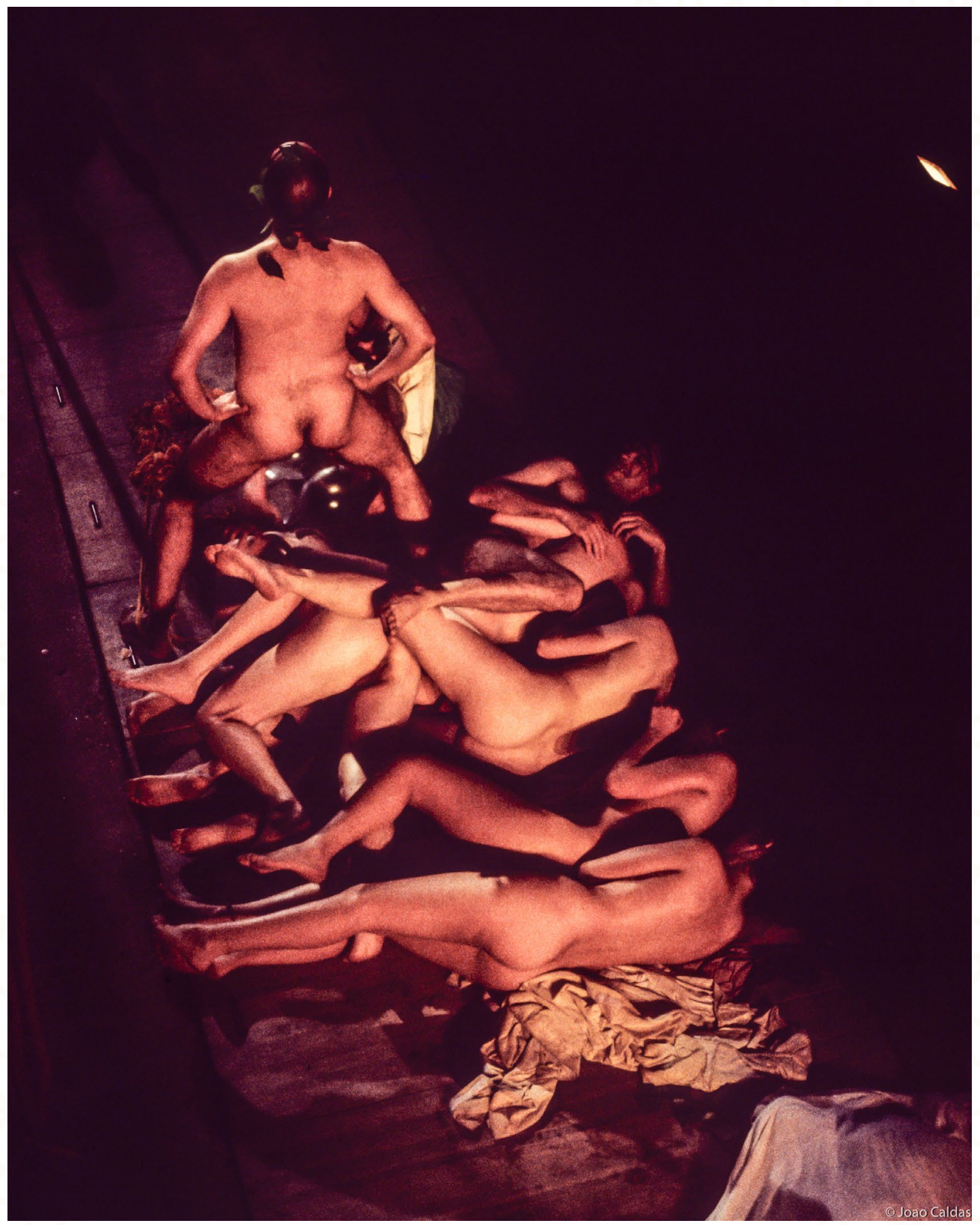




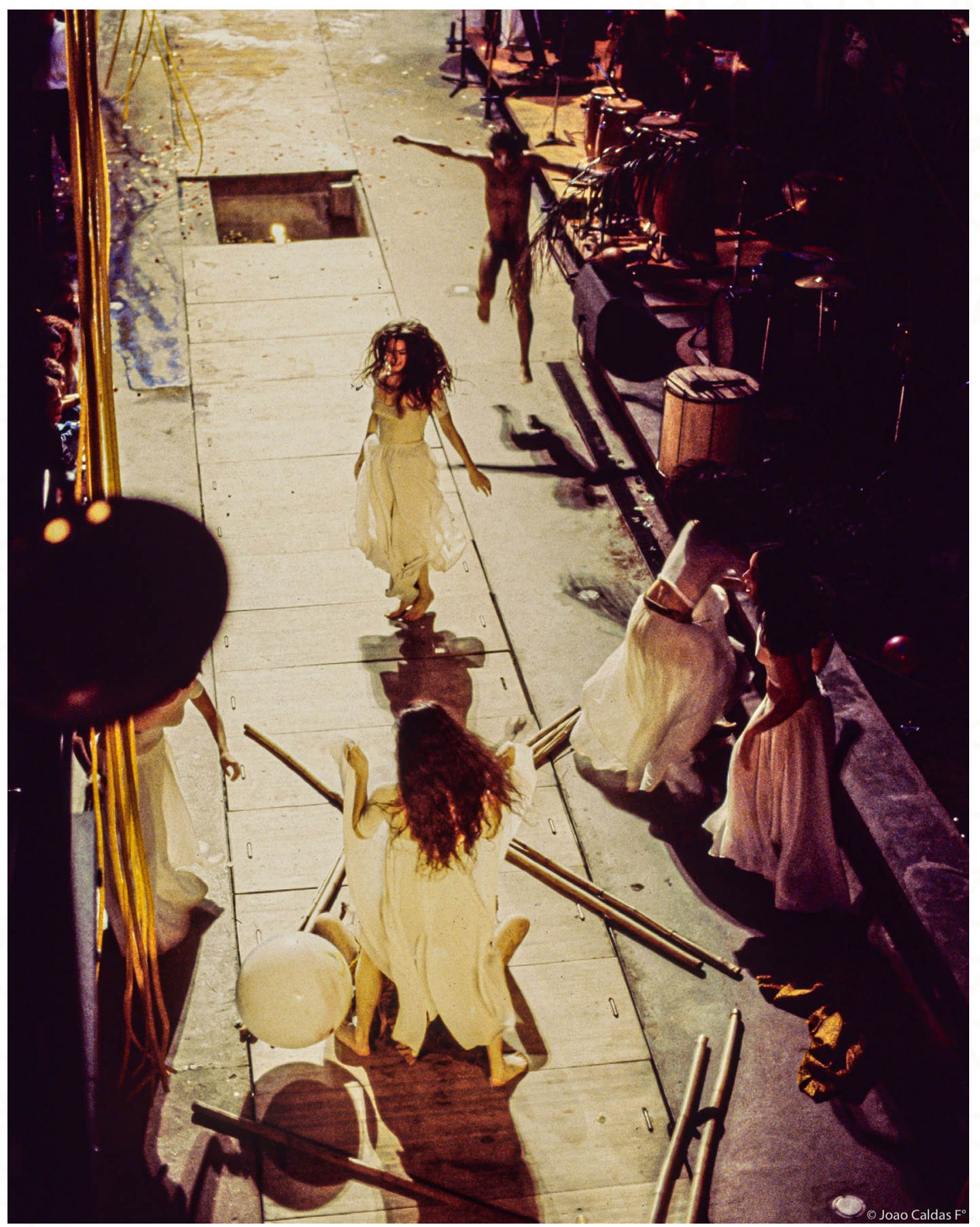




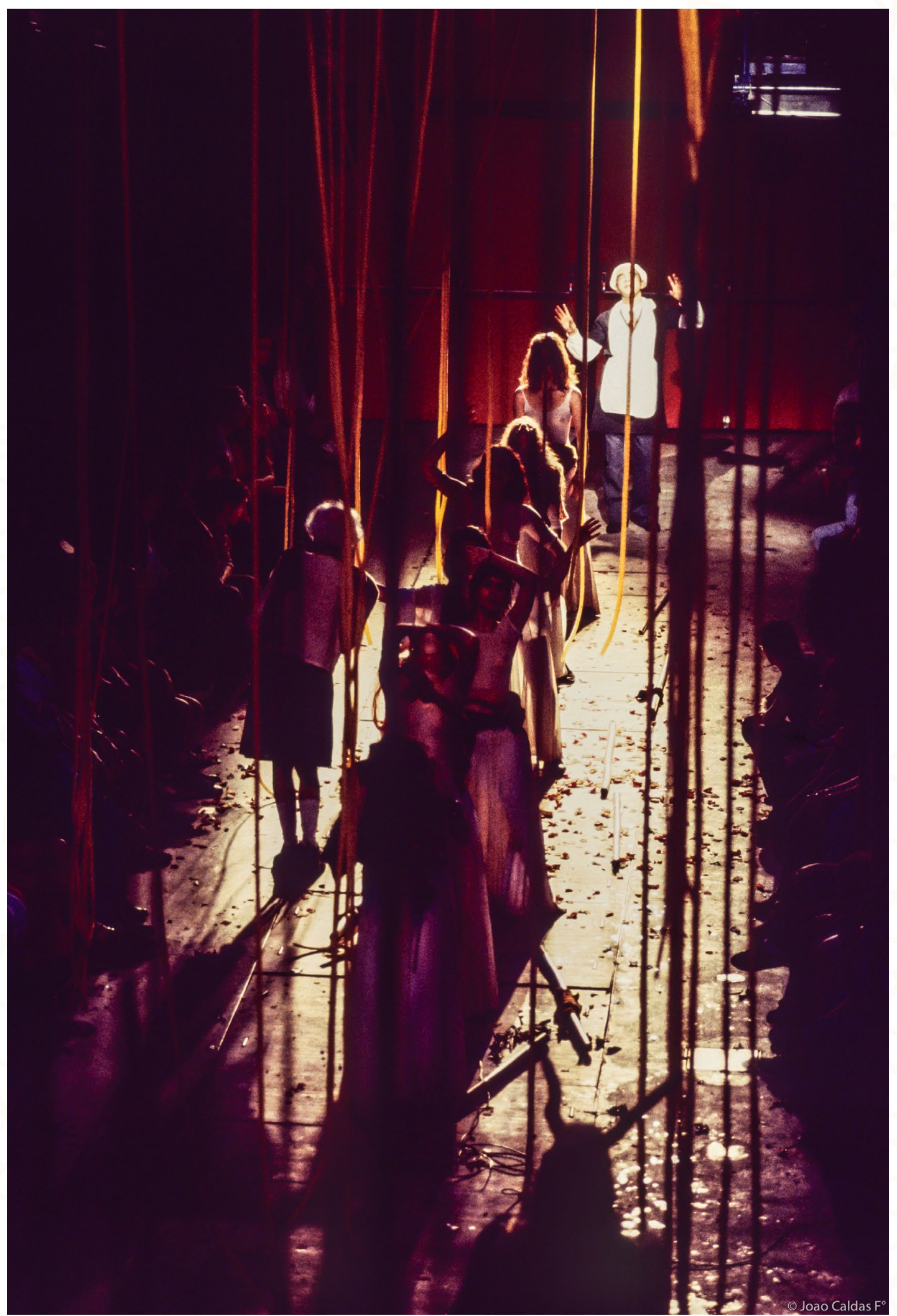




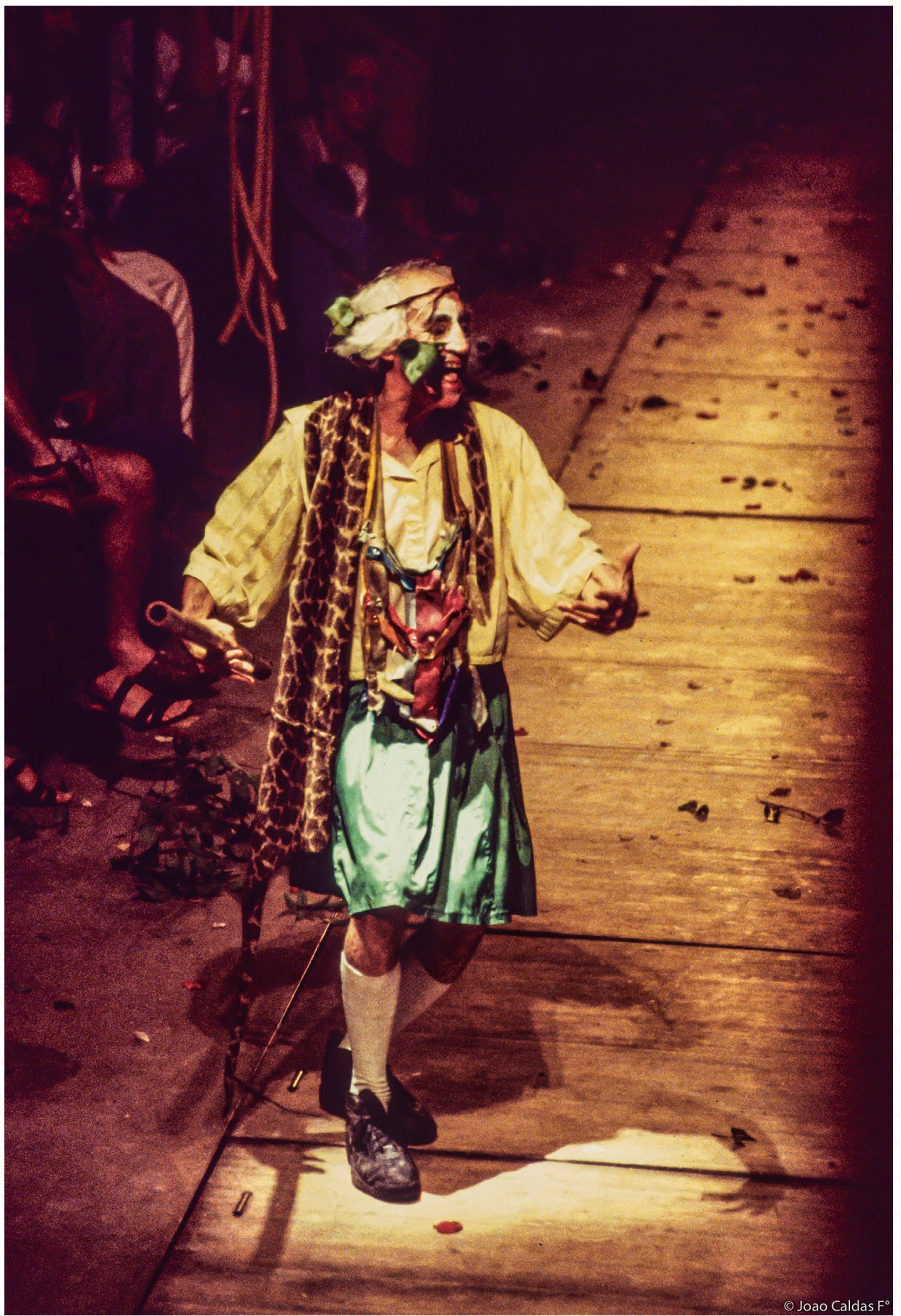




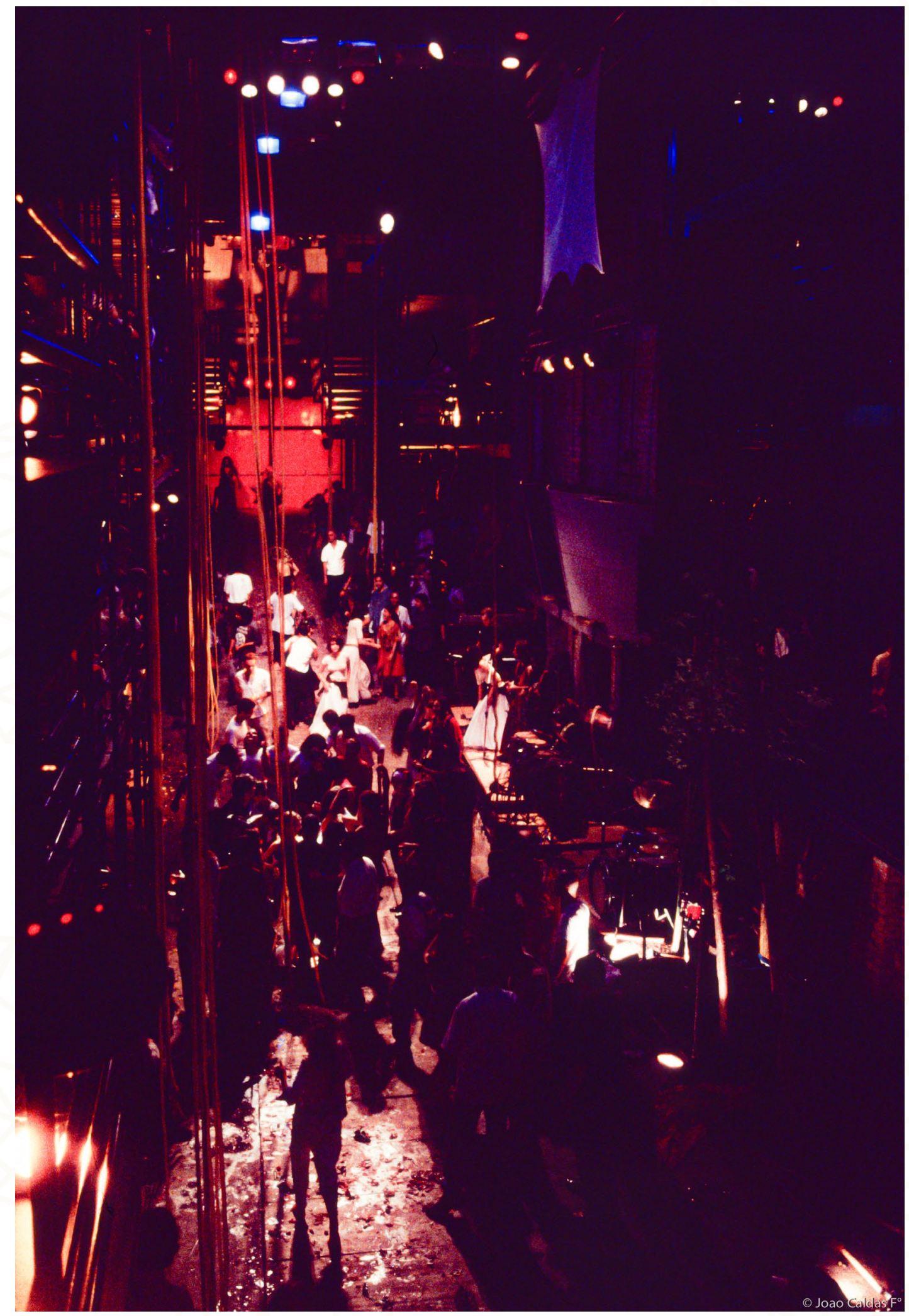




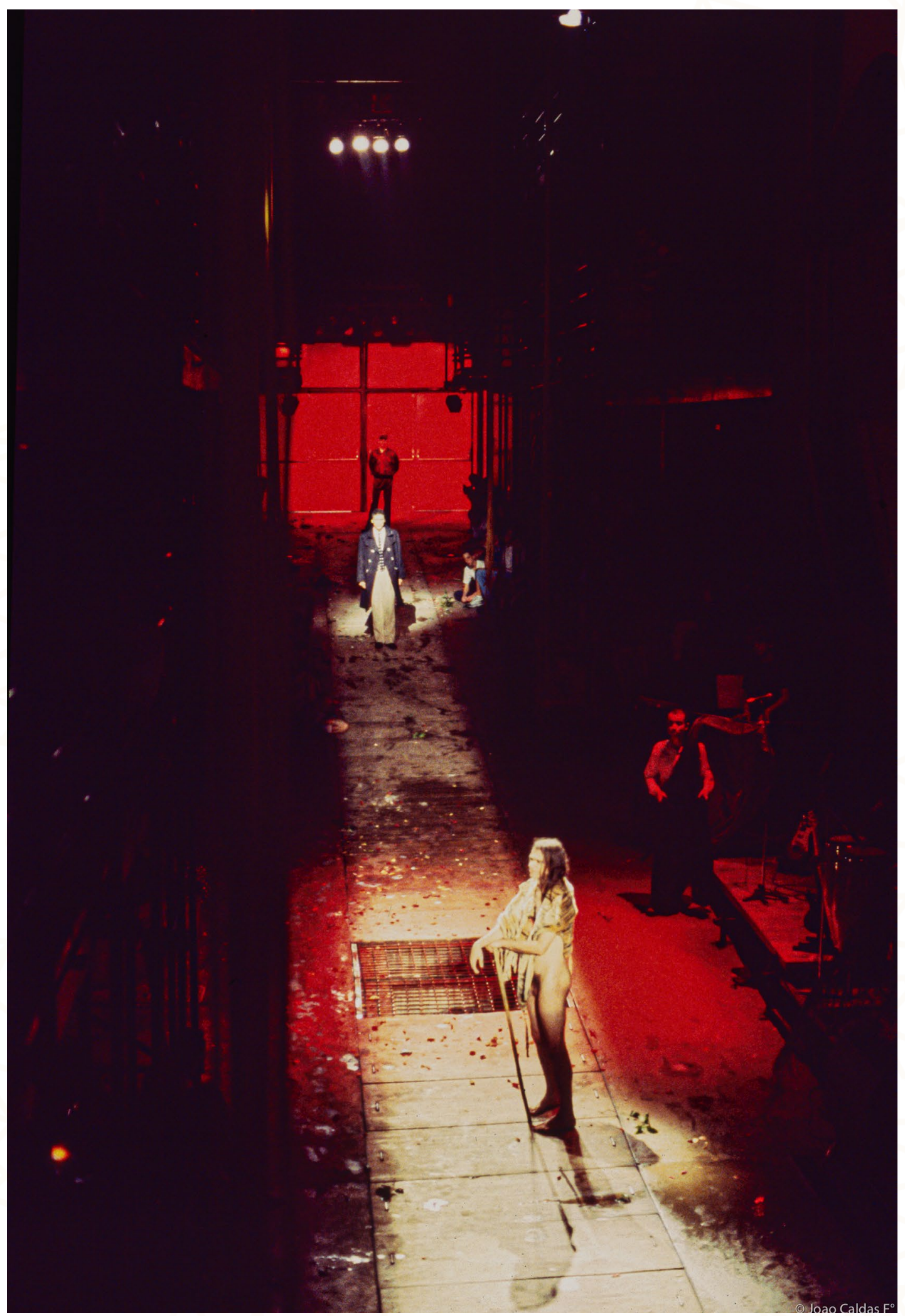




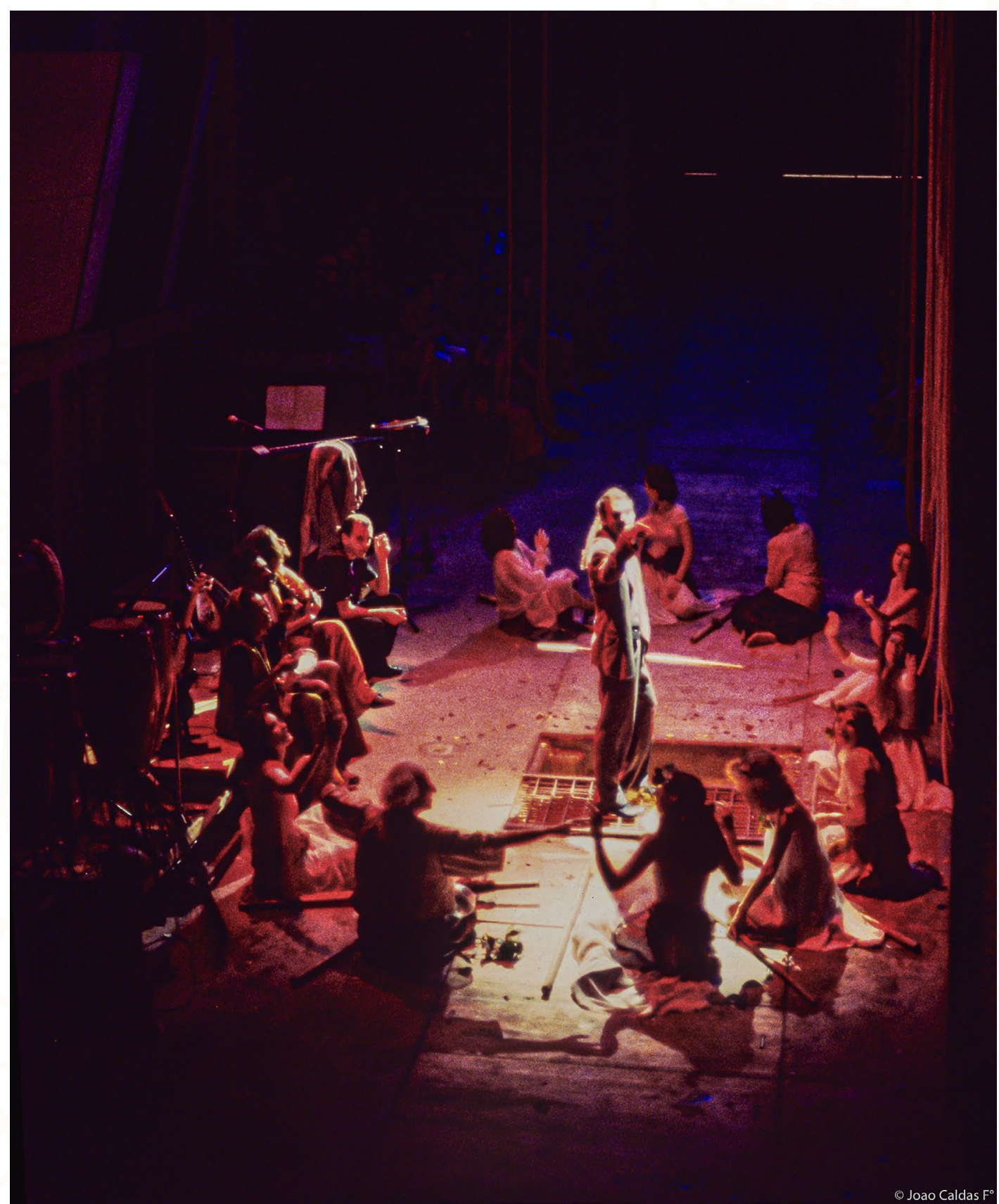




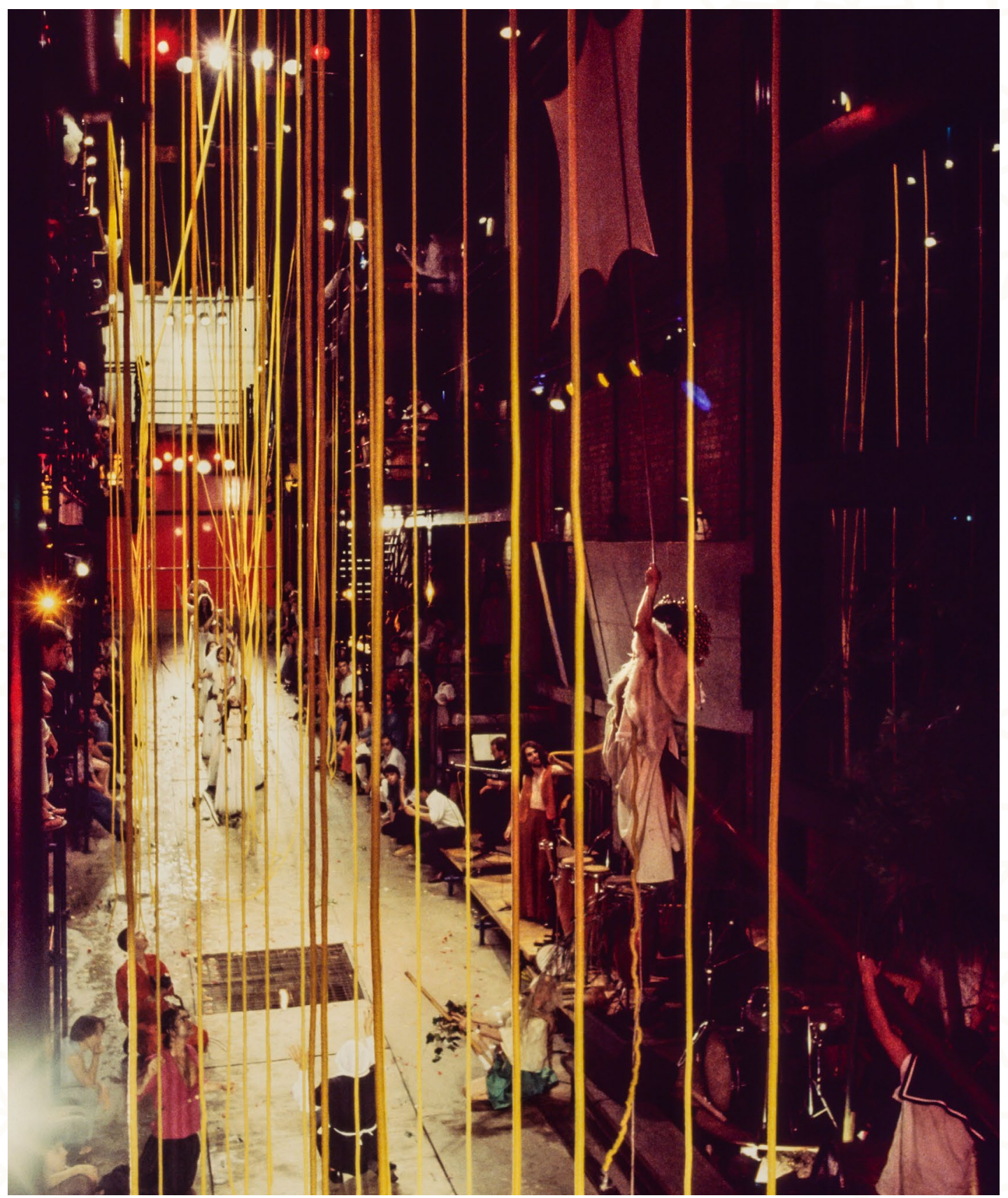




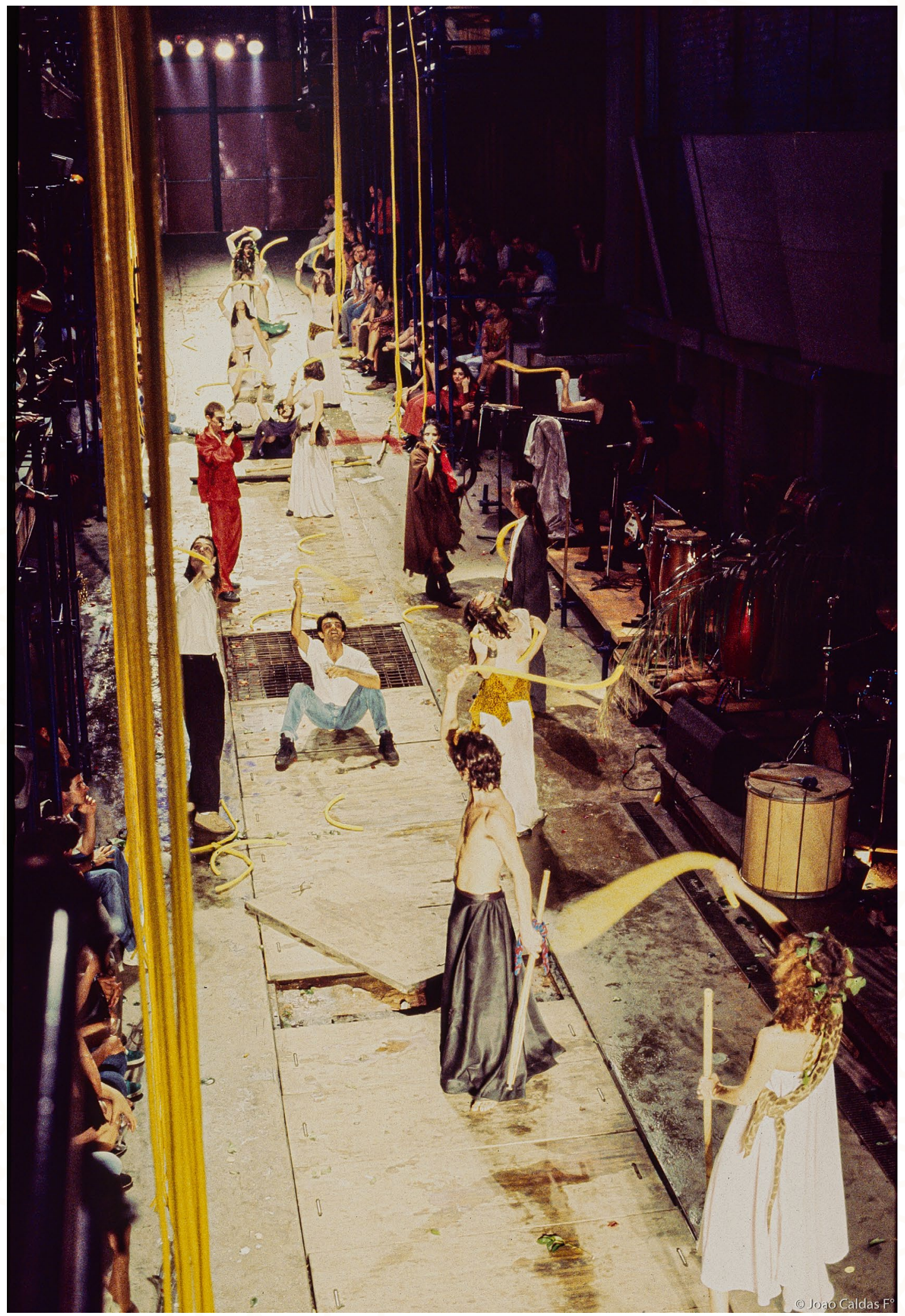




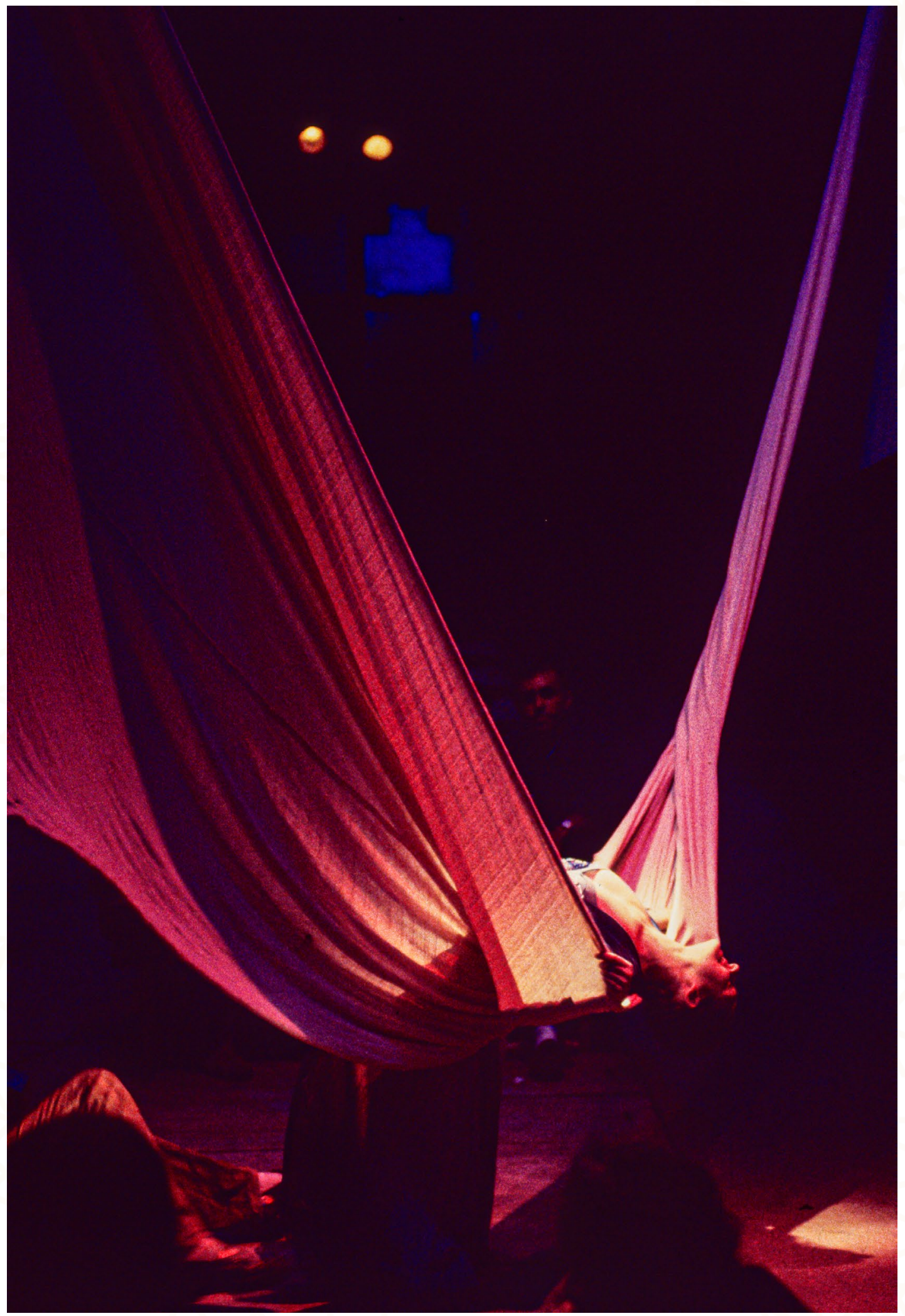



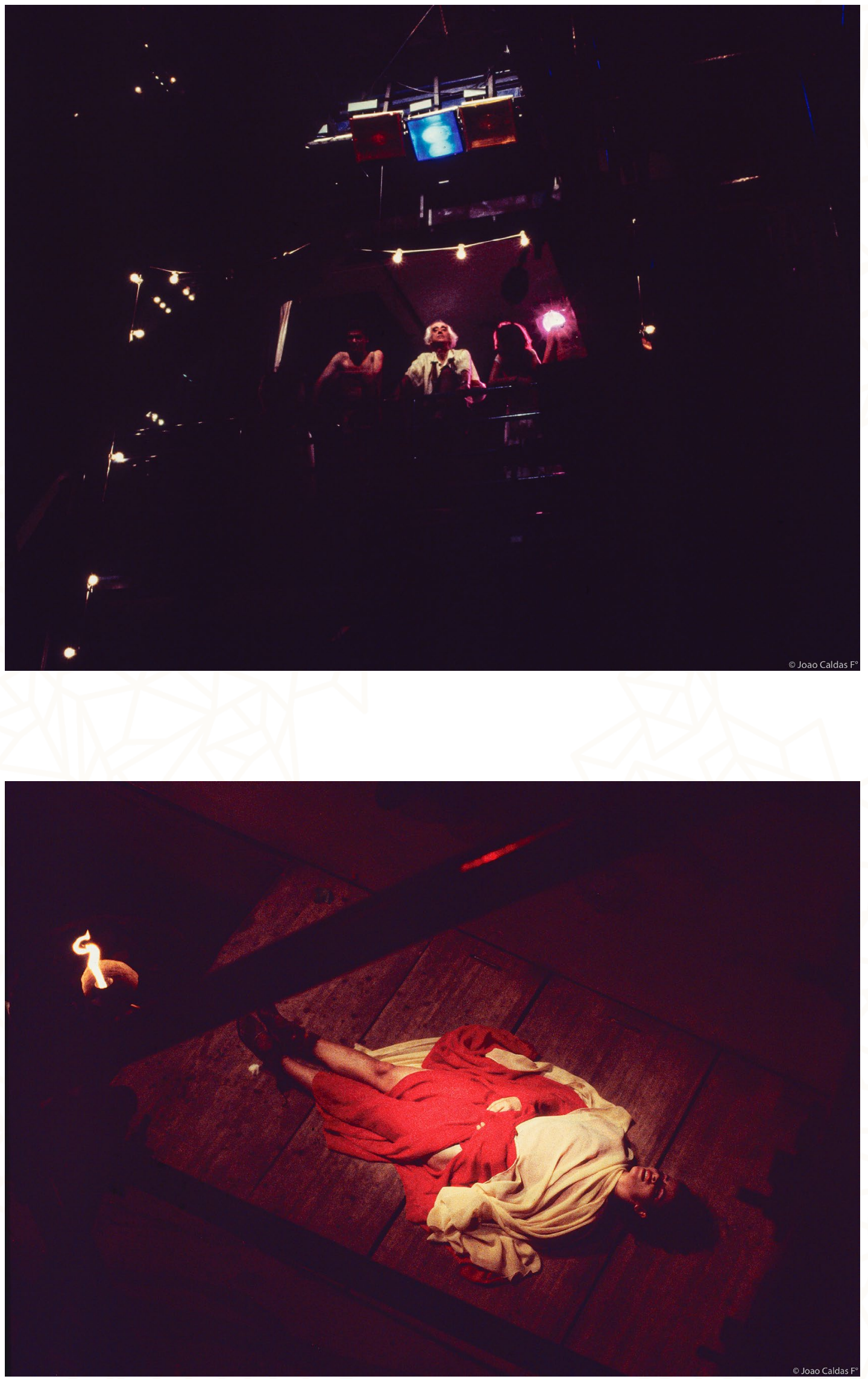


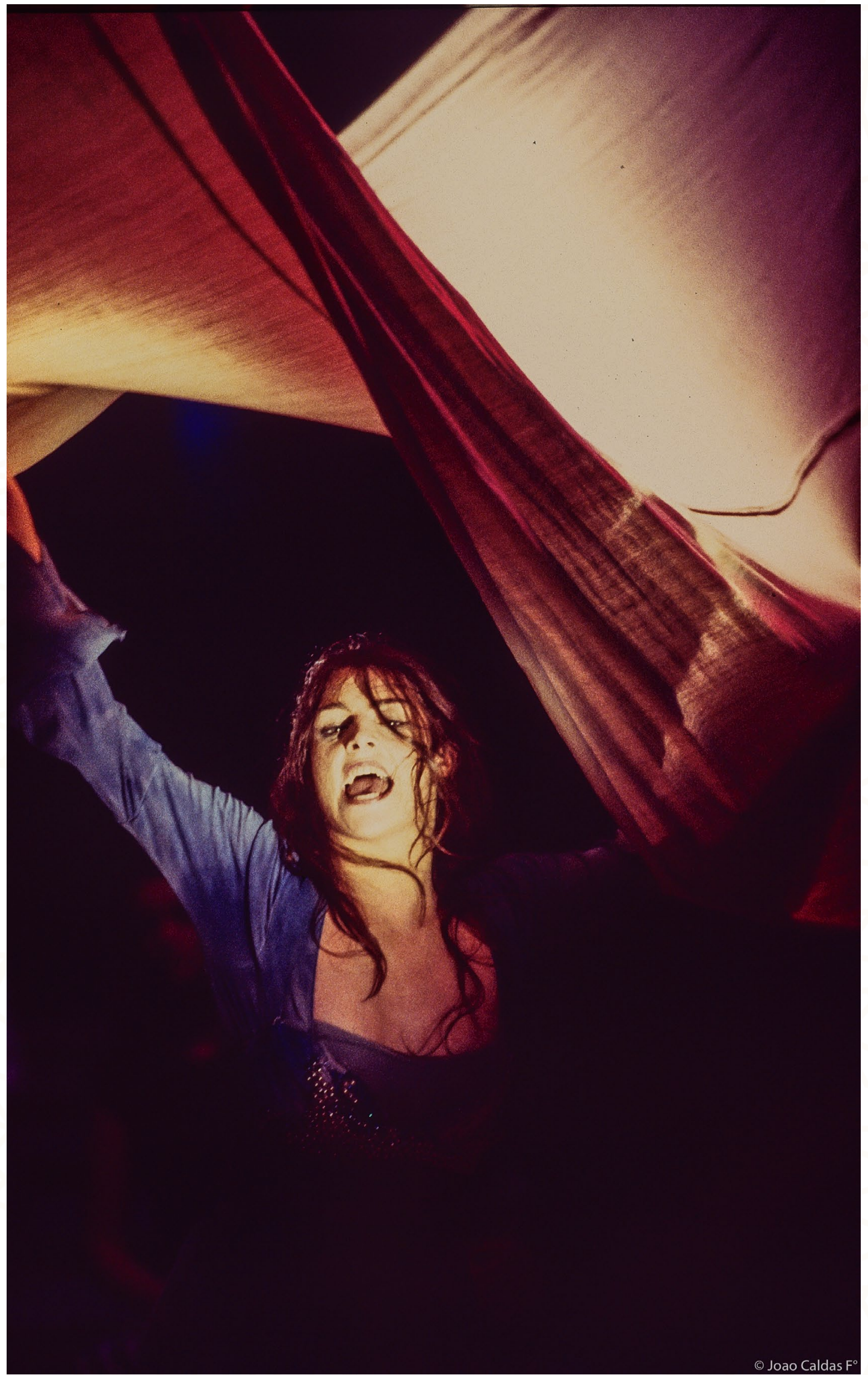

Revista sala preta | Vol.20| $\mathrm{n} .2$ | 2020 


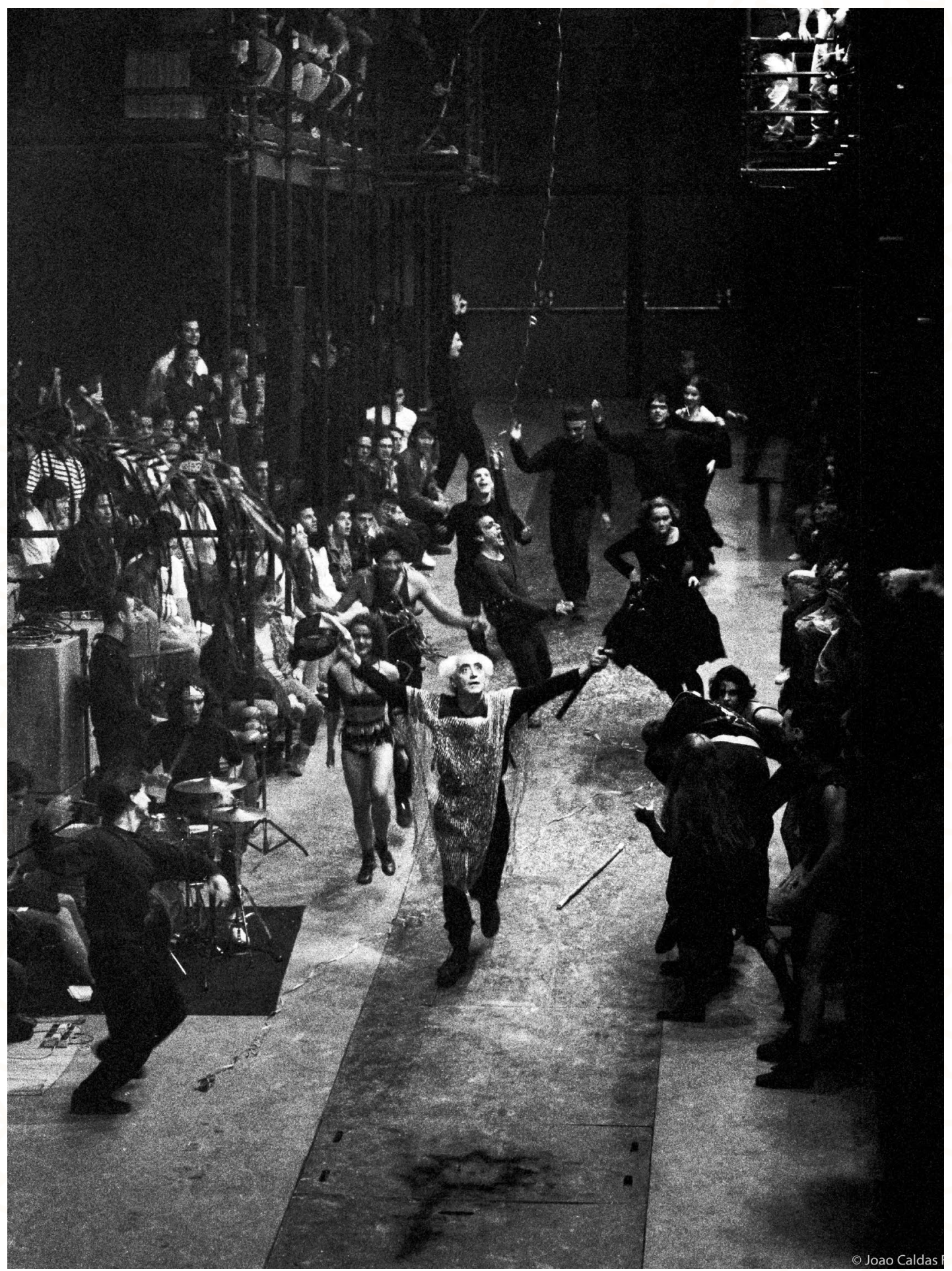




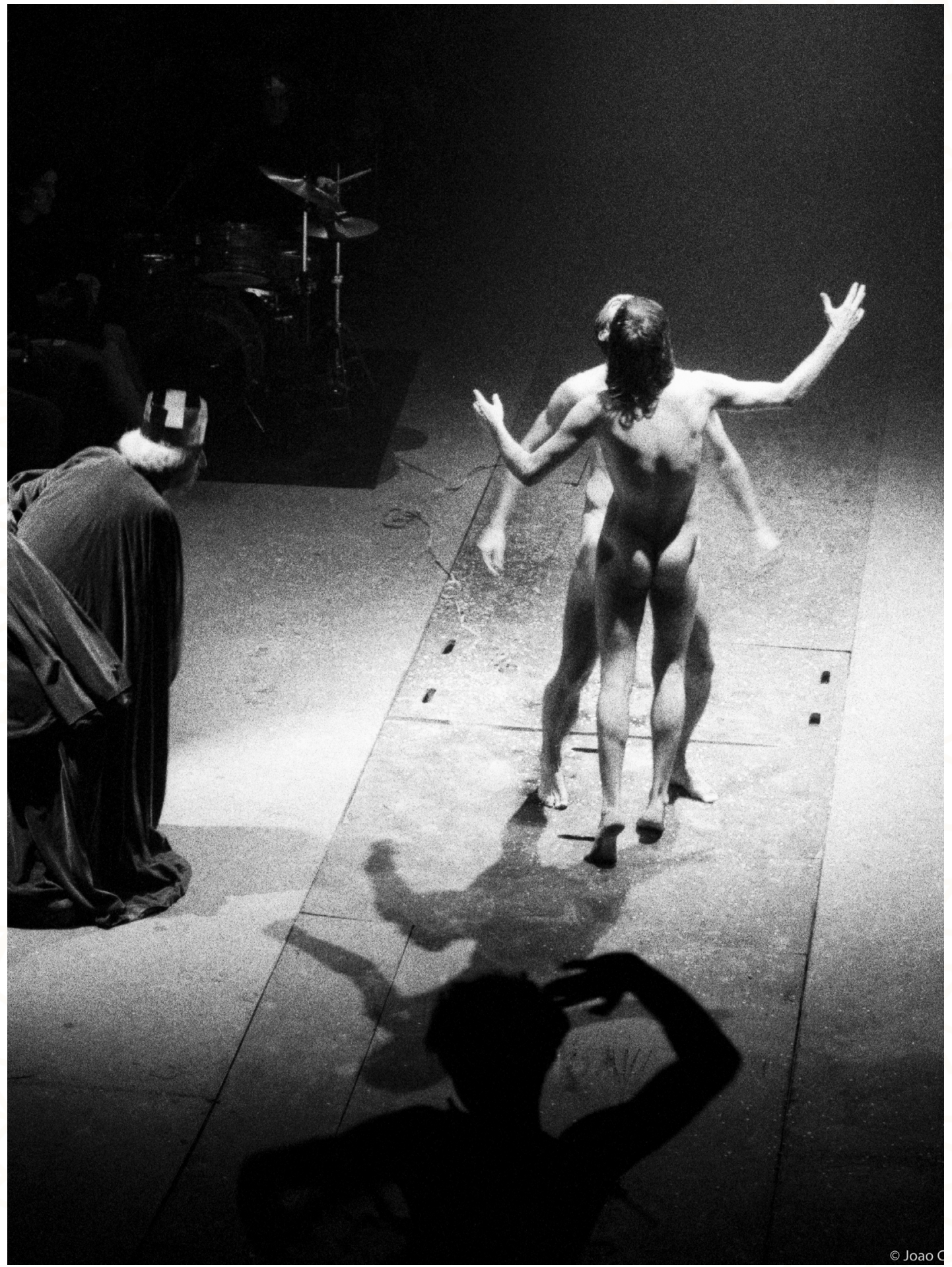




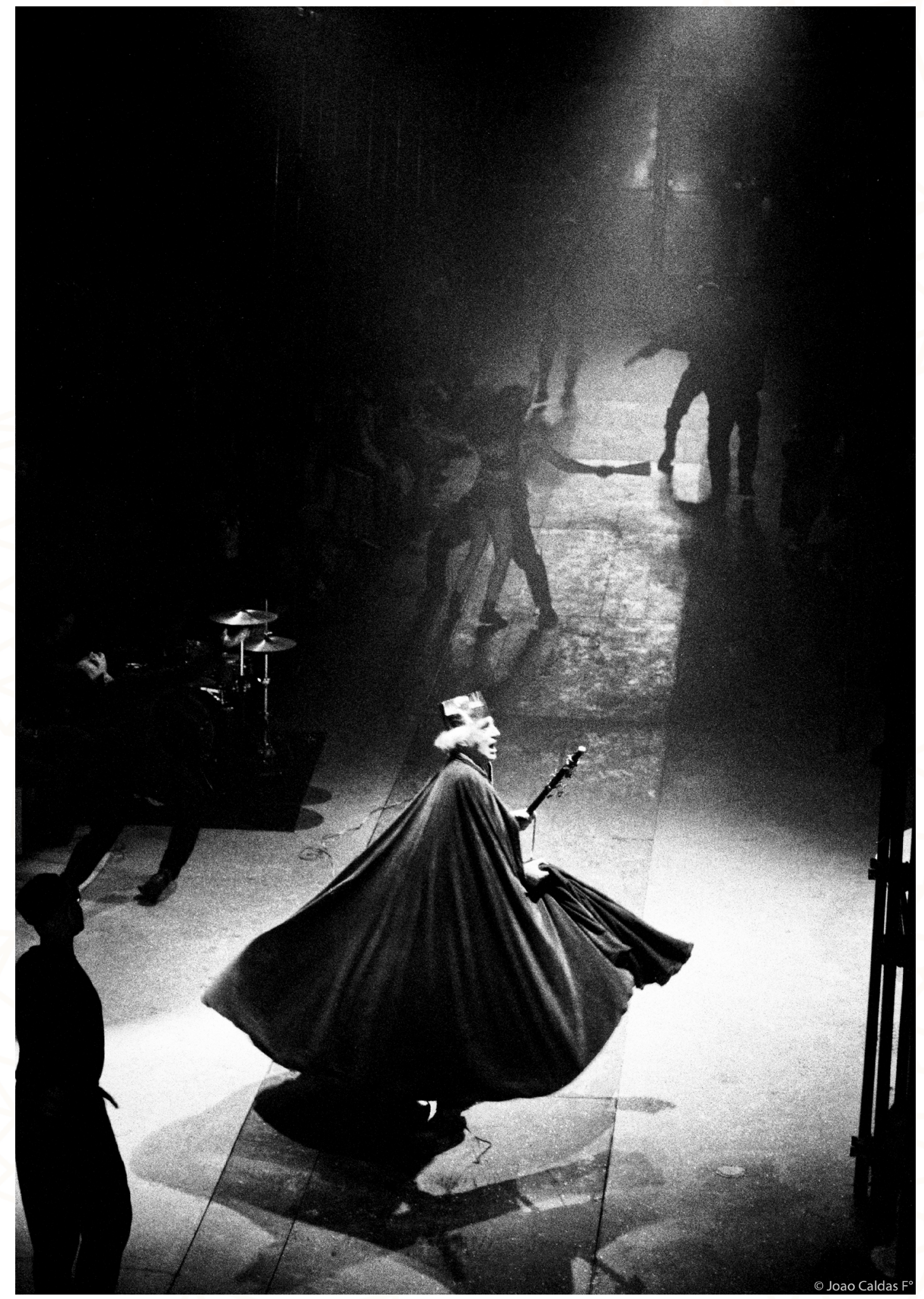




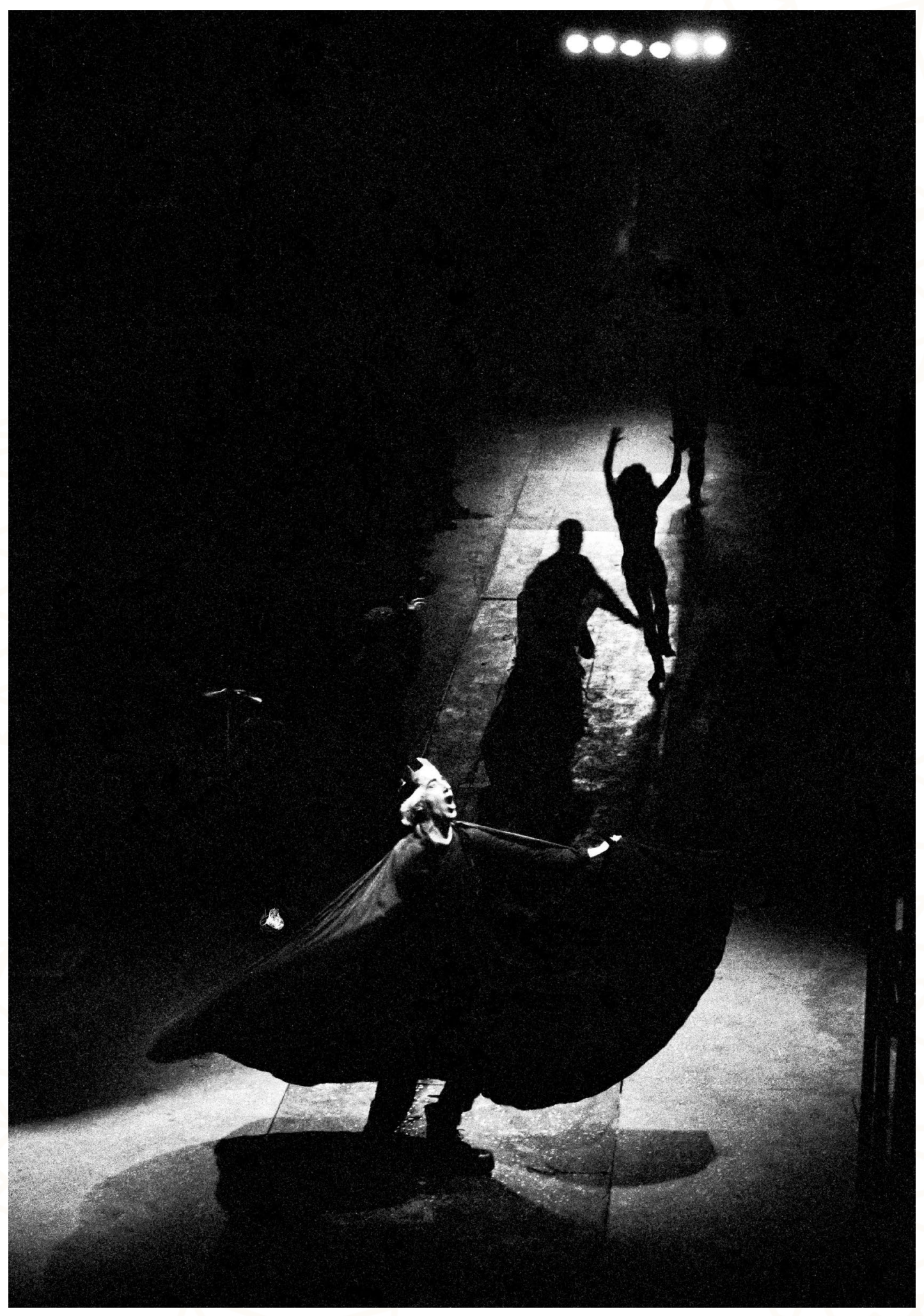



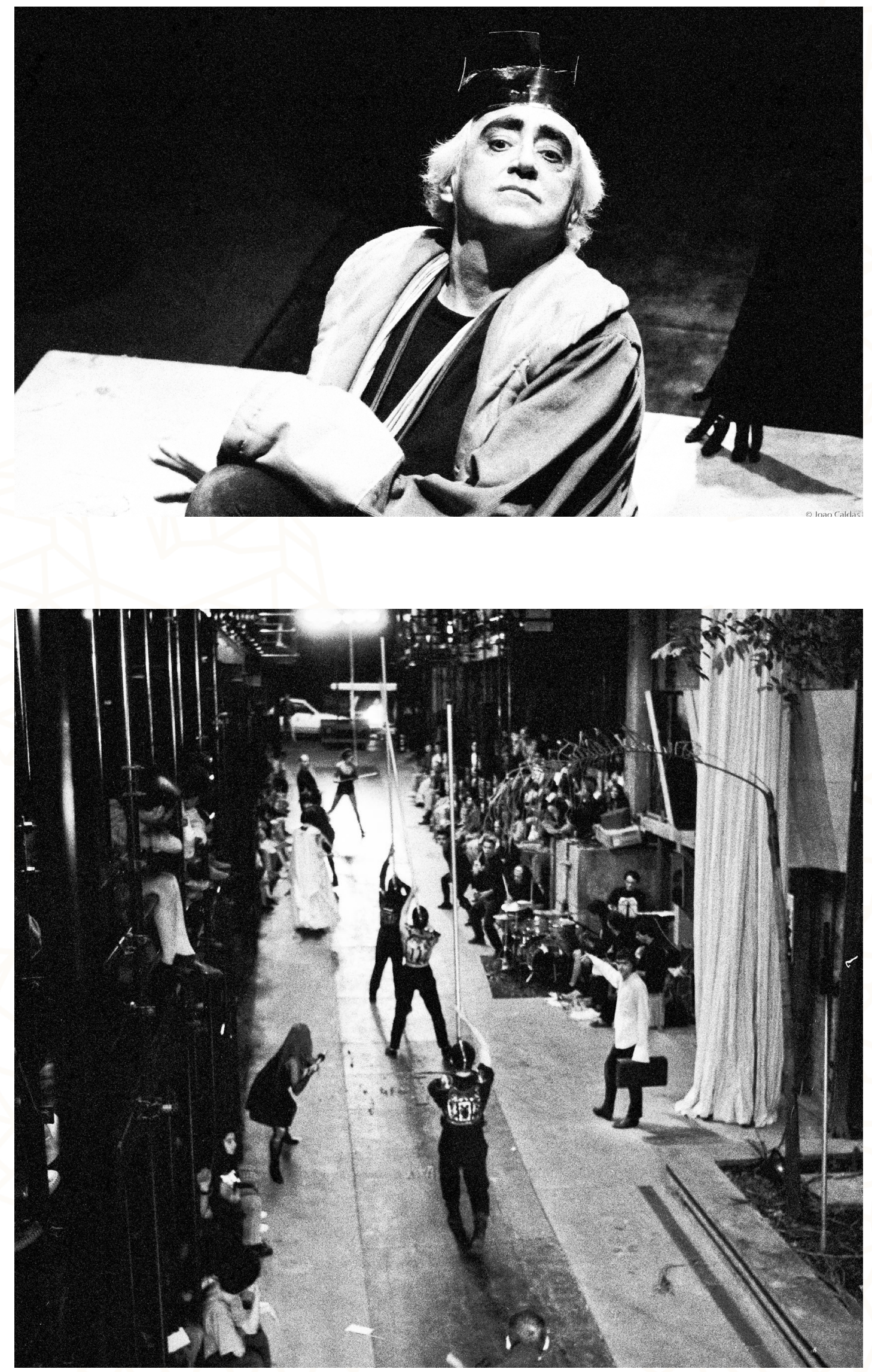


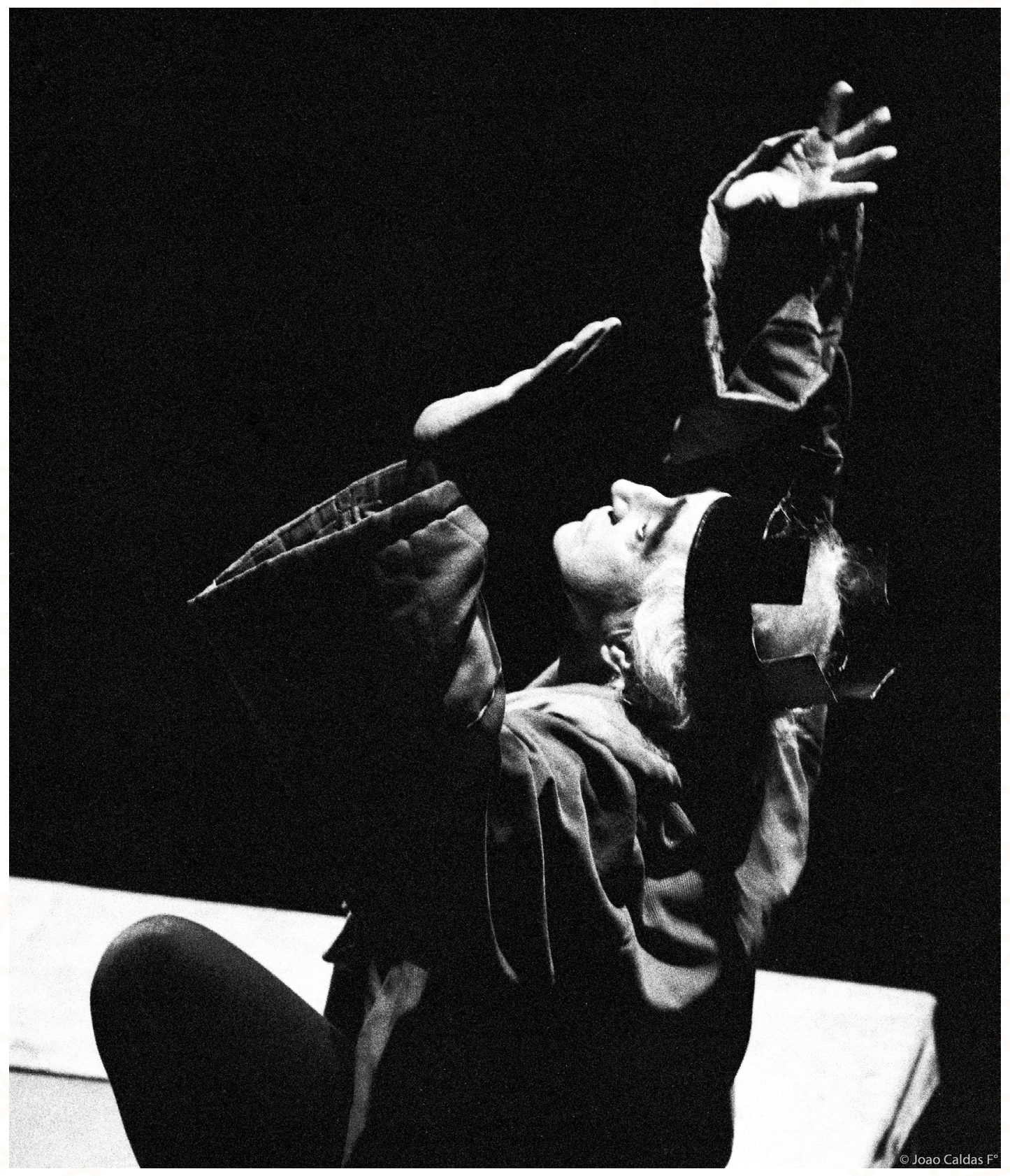




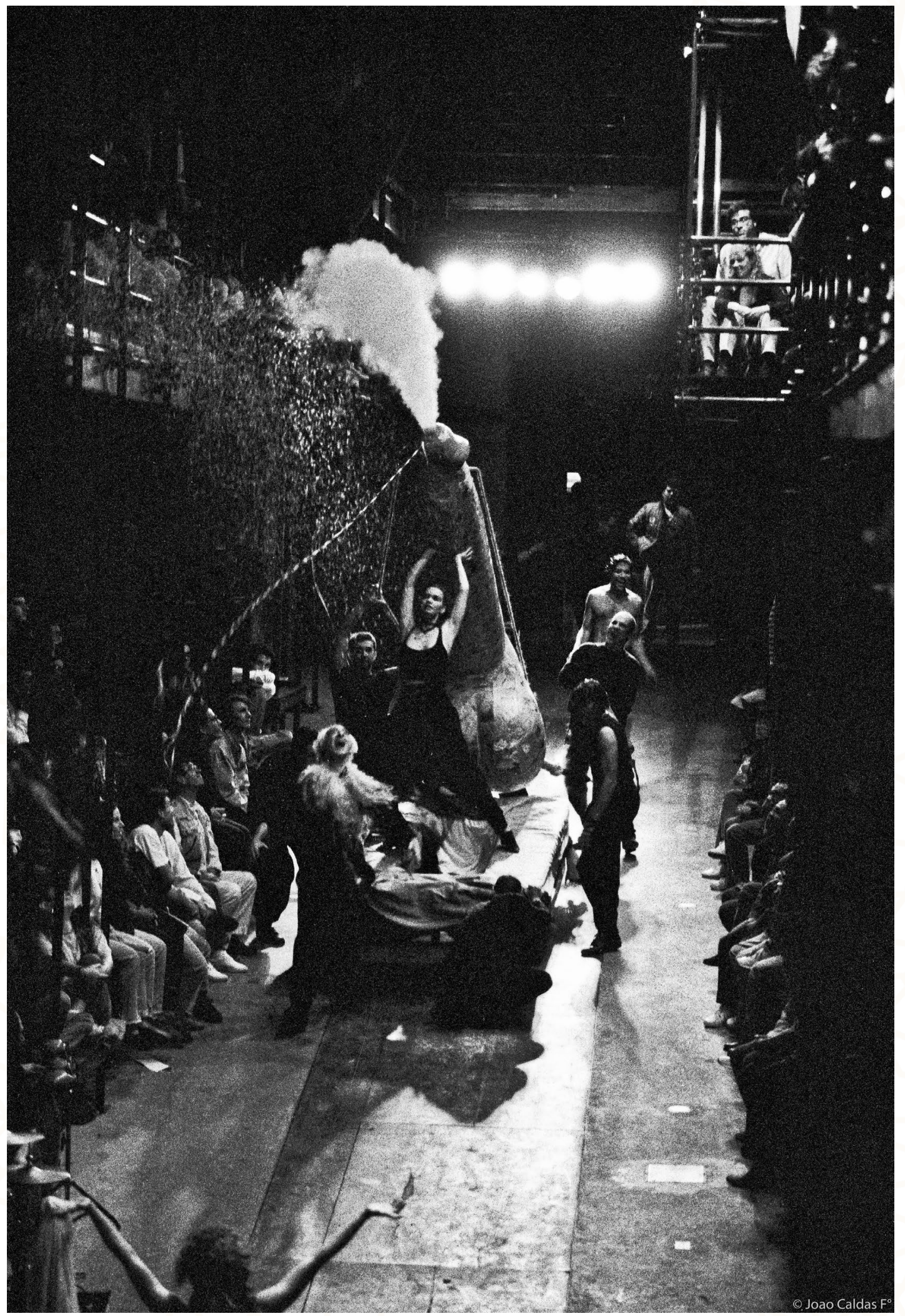

CJoão Caldas/FOLHAPRESS/1987 
Antes de fotografar um espetáculo no Teatro Oficina, tive a oportunidade de fotografar Zé Celso quando era repórter fotográfico na Folha de S.Paulo em 1987. Foram 2 ou 3 vezes, nas obras do teatro Oficina e em um encontro com Silvio Santos para discutir o tombamento da área em torno do teatro, que seria reconstruído e onde o empresário pretendia construir um prédio e até um shopping center. O Zé Celso que tive a oportunidade de conhecer nesses encontros profissionais era sempre vibrante e vulcânico, deixava o fotógrafo livre para criar, mas que também propunha ideias e poses que faziam das pautas uma alegria.

Alguns anos depois, em 1993, com o teatro inaugurado e em pleno funcionamento, retornei para fotografar alguns dos espetáculos em que Zé Celso atuava e também dirigia. Cheguei ao Oficina por meio dos pesquisadores do Arquivo Multimeios da Divisão de Pesquisas do Centro Cultural São Paulo, onde registrei mais de uma centena de espetáculos entre os anos de 1983 e 1996. O arquivo é umas das preciosidades que temos disponível ao público em São Paulo, com um acervo imenso de imagens, textos, cartazes, programas e gravações de peças de teatro, além dos espetáculos de dança, cinema e artes plásticas.

No meu ofício de 40 anos registrando espetáculos de teatro, já estive em muitas salas, espaços alternativos, praças, galpões, estação de metro, sambódromo, casas antigas, lonas, museus e na rua, capturando várias montagens de teatro, dança, música, circo e performances. Mas nada chega perto do que acontece no Teat(R)o Oficina Uzyna Uzona. Pergunto-me se existe alguma coisa parecida ao Oficina, já pelo nome diferente e simbólico. No verbete, oficina é o "lugar onde se exerce um ofício, fábrica, laboratório, usina, local para elaborar, fabricar, consertar". Todos esses sinônimos representam o teatro Oficina, que vai muito além das outras casas de espetáculos e dos teatros que conhecemos habitualmente.

Em dezembro de 2015, o teatro Oficina foi eleito o melhor teatro do mundo na categoria "projeto arquitetônico" pelo The Observer, jornal britânico publicado aos domingos e associado ao The Guardian: "O Teatro Oficina tem ângulos de visão desafiadores, assentos duros e uma forma que é exatamente a que os teatros não deveriam ter, mas é tanto mais intenso precisamente por isso"1 (MOORE, 2015, tradução nossa).

1 No original: "Teatro Oficina has challenging sight lines, hard seats and is very much not the shape theatres are meant to be, but is all the more intense for that". 
Tenho que concordar quando o artigo do The Observer diz que é uma forma que os teatros não deveriam ter, pois dentro do Oficina todos os padrões teatrais são quebrados. Só uma cabeça genial como a de Zé Celso poderia dominar aquele espaço e transformá-lo em tudo, até em teatro.

Lembro que quando ia ao Oficina para fotografar os espetáculos de Zé Celso, eu me preparava psicológica, técnica e fisicamente, pois eram apresentações longas, intensas e cheias de surpresas. As peças que registrei nesse espaço inusual foram Ham-let, em 16 de dezembro de 1993, Os Mistérios Gozozos, em 30 de março de 1995, Para dar um Fim no Juizo de Deus, em 5 de dezembro de 1996 e As Bacantes que, por sua complexidade, foi fotografado em duas ocasiões, 13 de dezembro de $1996 \mathrm{e}$ 20 de dezembro de 1996.

A caixa comprida, alta, sem um palco tradicional, sem plateia convencional, sem urdimento, sem bastidores, sem cortina, sem boca de cena, onde não existe a caixa preta das salas de espetáculos, me deixava sempre ansioso, tenso e dasafiado para fotografar. O palco-rua, estreito e inclinado, e a plateia, em andaimes sobrepostos com uma estrutura de ferro pesada e onipresente em todos os ângulos de visão, sempre fora, um desafio para este fotógrafo-documentador, que tinha que registrar o espetáculo como um todo, mostrando as cenas, o espaço, a luz, o cenário, os adereços e as interpretações do elenco. Tudo isso é relativamente simples de fazer em um palco italiano, mas não no Oficina! Naquele espaço não tem palco, cenário nem plateia; tudo se mistura e se confunde. Existem muitas possibilidades de visão: de cima, de lado, no nível do chão e até dentro da cena ou na passagem das cenas e do desfile. Nas montagens havia sempre essas cenas em desfile e, muitas vezes, com várias passagens de ida e volta no longo corredor que pode ser aberto no centro como um fosso, muito usado nos espetáculos. $O$ fotógrafo tem toda a liberdade de se deslocar para onde quiser e quando quiser e, em muitos momentos, a visão fica prejudicada pela estrutura de ferro dos andaimes, e é quase impossível ter uma visão limpa do espetáculo. Para o público, torna-se uma experiência sensorial e intensa e em alguns espetáculos até mesmo interativa.

A rua sempre fez parte do teatro de Zé Celso e no Oficina de hoje alguns espetáculos começam na rua, com o público e a trupe entrando naquele que 
se transforma no templo de uma celebração teatral. Outros espetáculos terminam ganhando a rua numa grande apoteose e celebração do elenco junto ao público. É um mérito do projeto do espaço, que interage com a cidade, e de Zé Celso, que abre suas portas e põe o teatro na rua, quebrando a distância do público que ainda fica longe das salas de teatro fechadas, elitizadas e praticamente inacessíveis à grande maioria.

Como registrar tudo isso com uma câmera fotográfica e com os filmes contados que tínhamos? Três a quatro filmes BxP de 36 poses e um ou dois filmes de slides coloridos, num total aproximado de 180 a 200 clics para espetáculos de três a quatro horas, com elencos numerosos, muita ação, muita música e muito tudo... Era sempre desafiador, intenso e cansativo.

Os filmes da época tinham limites técnicos para poder fazer o registro com pouca luminosidade e muita movimentação das cenas. Hoje, revendo essas fotos, percebo que optei por registrar a grande dimensão dos espetáculos que aconteceram ali, com cenas mais abertas, feitas do alto, localizando o que acontecia dentro daquele espaço particular, onde a visão era ruim, os bancos duros e desconfortáveis e tudo acontecia ao mesmo tempo em vários lugares. Sem contar o chamado do elenco para a participação do público, quando muitas cenas viravam happenings coletivos que podiam acontecer a cada noite de um jeito diferente.

Com isso, o meu jeito de fotografar, discreto, cuidadoso, silencioso e estático nos teatros convencionais para respeitar o público e não incomodar os atores, teve que voltar aos tempos do fotojornalismo e ir atrás do que estava acontecendo. Lembro que, para as fotos no Oficina, voltei a usar o colete de fotojornalista, com o equipamento junto ao corpo para poder me deslocar com agilidade durante as apresentações, um comportamento impensável em outros treatros

Zé Celso e todos do elenco davam toda a liberdade para fazermos os registros. Recentemente, quando estive lá assistindo Cacilda!, pude ver uma câmera de vídeo operada por um cinegrafista-ator no meio das cenas, mandando imagens dos detalhes destas cenas para os telões instalados no teatro. Observei muito o cinegrafista e fiquei admirado com sua desenvoltura. Ele fazia parte do elenco, era um dos atores, só que com a câmera na mão no meio das cenas. Acho que esse recurso foi uma boa solução para que o 
público, empoleirado nos andaimes, tivesse uma visão mais completa do que acontecia lá embaixo, na passarela-palco.

Com toda a particularidade do espaço do Oficina, os espetáculos de Zé Celso sempre foram muito bem feitos em termos técnicos, com o som ao vivo ou gravado, os efeitos visuais, as trilhas e a iluminação, tudo muito bem cuidado e com boa qualidade técnica.

Para escrever esse pequeno testemunho de minha experiência em fotografar no teatro Oficina, fui rever os trabalhos que fiz para o Arquivo Multimeios. Depois de tantos anos, ainda lembro muito bem de alguns momentos desses trabalhos. Mas, revendo as fotos, sinto que as imagens não conseguem alcançar a dimensão e a intensidade do que é estar presente em uma peça de Zé Celso no Teatro Oficina. As imagens dão uma pequena idéia do que aconteceu lá e valem como documento precioso de um artista especialíssimo como ele e do que foi feito naquele espaço único.

Há diferentes registros fotográficos desses espetáculos, inclusive de fotógrafos residentes, que acompanharam intimamente todo o processo de construção das cenas. Mas são registros espalhados nos arquivos pessoais desses profissionais e em algumas publicações.

Para os que lá puderam estar presentes, guardem as sensações que tiveram ao vivenciar a experiência de assistir a um espetáculo de Zé Celso no Teatro Oficina. Vocês são poucos e privilegiados. Para os que nunca foram ao Oficina, recomendo muito a experiência presencial. Nestes tempos que estamos vivendo de pandemia, enquanto escrevo esse texto me dá uma saudade enorme do que nos foi permitido fazer e viver numa época em que o contágio era da alegria, do calor, dos cheiros, dos corpos e das vibrações que aconteciam nos espetáculos.

EVOÉ!

\section{Referências bibliográficas}

MOORE, R. The 10 best theatres. The Guardian, London, 11 dez. 2015. Disponível em: http://bit.ly/2LJkoal. Acesso em: 10 fev. 2021.

Autor convidado 